\title{
Epithelial cells as phagocytes: apoptotic epithelial cells are engulfed by mammary alveolar epithelial cells and repress inflammatory mediator release
}

\author{
J Monks ${ }^{1}$, D Rosner ${ }^{1}$, F Jon Geske ${ }^{1}$, L Lehman ${ }^{1}$, L Hanson ${ }^{2}$, \\ MC Neville ${ }^{2}$ and VA Fadok ${ }^{*, 1}$ \\ 1 Program in Cell Biology, D509, Department of Pediatrics, National Jewish \\ Medical and Research Center, Denver, CO, USA \\ 2 Department of Physiology and Biophysics, University of Colorado Health \\ Sciences Center, Denver, Colorado, USA \\ * Corresponding author: VA Fadok, Program in Cell Biology, D509, Department \\ of Pediatrics, National Jewish Medical and Research Center, Denver, CO \\ 80206, USA. E-mails: fadokv@njc.org, monksj@njc.com
}

Received 03.3.04; revised 22.6.04; accepted 22.6.04

Edited by T Ferguson

\begin{abstract}
Clearance of apoptotic cells is critical to tissue homeostasis and resolution of inflammatory lesions. Macrophages are known to remove dying cells and release anti-inflammatory mediators in response; however, many cells traditionally thought of as poor phagocytes can mediate this function as well. In the lactating mammary gland following weaning, alveolar epithelial cell death is massive, yet the gland involutes rapidly, attaining its prepregnancy state in a matter of days. We found histologic evidence of apoptotic cell phagocytosis by viable mammary epithelial cells (MEC) in the involuting mouse mammary gland. Cultured MEC were able to engulf apoptotic cells in vitro, utilizing many of the same receptors used by macrophages, including the phosphatidylserine receptor (PSR), CD36, the vitronectin receptor $\alpha_{v} \beta_{3}$, and CD91. In addition, MEC, like macrophages, produced TGF $\beta$ in response to stimulation of the PSR by apoptotic cells or the anti-PSR ab 217G8E9, and downregulated endotoxin-stimulated proinflammatory cytokine production. These data support the hypothesis that amateur phagocytes play a significant role in apoptotic cell clearance and its regulation of inflammation. Cell Death and Differentiation (2005) 12, 107-114.

doi:10.1038/sj.cdd. 4401517
\end{abstract}

Keywords: apoptosis; phagocytosis; phosphatidylserine; receptors; cytokines; epithelial cells; mammary gland

Abbreviations: PSR, phosphatidylserine receptor; MEC, mammary epithelial cell; PMEC, primary MEC; CD91/LRP, low-density lipoprotein-related receptor; MBP, mannose-binding protein

\section{Introduction}

The mechanisms for recognition and engulfment of apoptotic cells by macrophages are legion, and have been reviewed in some detail. ${ }^{1-9}$ Many of these receptors are pattern recogni- tion receptors also utilized for uptake of microbial organisms or their byproducts. The paradox is that the consequences for the macrophage following uptake of microbes compared to those observed after uptake of apoptotic cells are diametrically opposed. Phagocytosis of microbial organisms is followed by a proinflammatory response, which enables the activation of a productive immune response. By contrast, apoptotic cells fail to induce inflammation and, in many cases, they induce an antiinflammatory reaction, thus presumably inhibiting an immune response. We have suggested that the difference lies in the fact that most pathogens fail to activate the receptor for phosphatidylserine (PSR), in contrast to apoptotic cells, which do. ${ }^{6}$ In fact, certain pathogens (trypanosomes, Leishmania spp.) have evolved ways to evade immune destruction precisely by utilizing the same anti-inflammatory mechanisms utilized by apoptotic cells. $^{10-12}$

Efficient removal of apoptotic cells is believed to be necessary for tissue development and homeostasis, as well as protection against neoplasia and chronic inflammation. The mammary gland provides a unique and ideal system in which to study the physiological removal of apoptotic cells, because it undergoes cycles of repetitive growth, death, and remodeling during the normal reproductive cycles of the adult female mammal. Given that macrophages have been shown to be dispensable with regard to apoptotic cell clearance, at least during development, ${ }^{13}$ and given the reported role for mammary epithelial cells (MEC) in apoptotic cell engulfment during involution, ${ }^{14}$ we chose to study MEC as a model 'amateur' phagocyte both in vivo and in vitro.

Little is known about receptors utilized for apoptotic cell uptake by epithelial cells or other 'amateur' phagocytes, yet it is clear that a variety of cells possess the ability to engulf apoptotic cells. These include epithelial cells, mesangial cells, vascular smooth muscle cells, hepatic cells, and endothelial cells. ${ }^{15-28}$ It has been shown that integrins and the PSR are used by lung alveolar epithelial cells in the engulfment of apoptotic eosinophils, ${ }^{15,16}$ but the consequences of apoptotic cell uptake on these amateur phagocytes are not known. Understanding how amateur phagocytes engulf and respond to apoptotic cells is important, because these cells can serve as important sources of cytokines (e.g. see Boudjellab et al. ${ }^{29,30}$ ), thus having the potential to contribute significantly to the inflammatory response. Epithelial cells, in particular, produce a variety of cytokines, and can initiate an inflammatory response themselves in response to noxious environmental stimuli.

In order to understand how epithelial cells recognize and respond to apoptotic cells, we studied phagocytosis during mammary gland involution in vivo, and modeled this process in vitro using the murine mammary epithelial cell lines $\mathrm{HC}-11^{31}$ and $\mathrm{EpH} 4,{ }^{32}$ as well as primary mammary epithelial cells (PMEC) isolated from mid-pregnant mice. MEC were able to act as phagocytes, in that they bound and engulfed apoptotic MEC, albeit much less efficiently than macrophages. They expressed 
and utilized many of the receptors used by macrophages, including the PSR; its stimulation in macrophages has been shown to cause membrane ruffling, rapid cytoskeletal actin reorganization, and macropinocytosis. ${ }^{33}$ In addition, following exposure to apoptotic cells, MEC-secreted TGF $\beta 1$ downregulated LPS-induced proinflammatory cytokine release. The implications of these findings are that epithelial cells can contribute significantly to apoptotic cell clearance in the involuting mammary gland, and that apoptotic cell uptake by amateur phagocytes warrants serious study in other organs.

\section{Results}

\section{Mammary epithelial cells engulf apoptotic bodies in vivo and in vitro}

We began our studies by histologic analysis of mammary glands induced to involute by forced weaning at day 14. The third and fourth glands on each side were harvested at various time points and processed for light and electron microscopy. During early involution, apoptotic epithelial cells were seen to be released from the basement membrane zone and were subsequently engulfed by their viable epithelial neighbors. Shed cells were evident within the lumen of an alveolus in routine hematoxylin and eosin-stained paraffin sections. (Figure 1a, arrow) Additionally, rounded apoptotic cells were
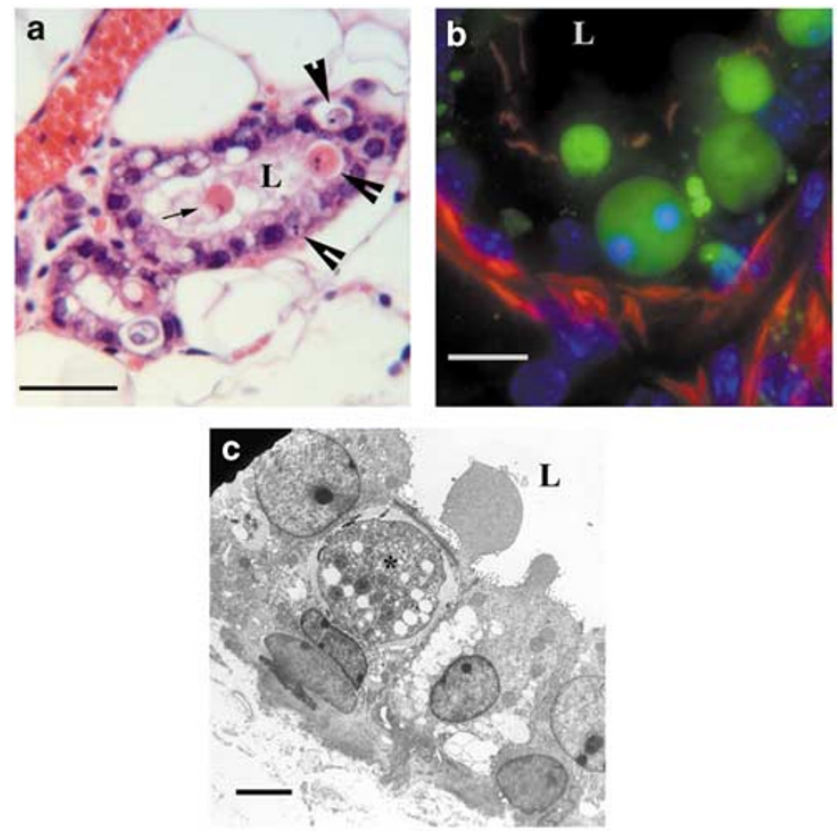

Figure 1 MEC engulf apoptotic cells in vivo. (a) Hematoxylin and eosin staining of paraffin-embedded tissue taken 3 days after weaning. Arrow shows an apoptotic cell shed into the lumen of the alveolus. Arrowheads point to apoptotic bodies, which appear to be contained within viable neighbors. Bar is $50 \mu \mathrm{m}$. (b) Frozen sections ( $8 \mu \mathrm{m}$ thick) of mammary gland tissue harvested 3 days after weaning were stained with Cytodeath, an antibody recognizing caspase-cleaved keratin-18, and counterstained with rhodamine-phalloidin and DAPI. Optical slices through the tissue are shown as the maximum intensity projection of the data. Intact and fragmented apoptotic bodies within phagosomes in viable epithelial cells are shown. Bar is $10 \mu \mathrm{m}$ (c). Electron micrograph of an engulfed apoptotic cell (asterisk) within a mammary epithelial cell, 1.5 days postwean. The lumen of the alveolus is marked with an $\mathrm{L}$. Bar is $5 \mu \mathrm{m}$ found within phagosomes in healthy cells within the epithelial monolayer. (Figure 1a, arrowheads) These cells were shown to be apoptotic both by morphology in electron micrographs (Figure 1c) and by immunostaining with an antibody to caspase-cleaved keratin-18 (Figure 1b).

In order to begin to describe the mechanisms used by MEC to clear apoptotic cells during gland remodeling, we used the murine mammary epithelial cell lines $\mathrm{HC}-11$ and $\mathrm{EpH} 4$, as well as PMEC isolated from mid-pregnant mice. Figure 2 shows that both HC-11 MEC, which have a more mesenchymal phenotype, and $\mathrm{EpH} 4$ cells, which have a polarized epithelial phenotype, bound and engulfed apoptotic $\mathrm{HC}-11$ cells. Figure $2 a$ shows a fluorescent photomicrograph showing the engulfment of apoptotic HC-11 cells (stained red) by HC-11 and $\mathrm{EpH}-4$ cells (stained green). In Figure 2b, an electron micrograph shows $\mathrm{HC}-11$ cells, which have bound and engulfed apoptotic bodies showing condensed chromatin, as well as smaller membrane bound bodies derived from latestage apoptotic cells

\section{Mammary epithelial cells express and utilize many receptors for phagocytosis of apoptotic cells}

Flow cytometry analysis (Figure $3 a$ ) shows that the MEC expressed CD36 and the $\alpha_{\mathrm{v}} \beta_{3}$ integrin (vitronectin receptor, $\mathrm{VnR}$ ), implicated in apoptotic cell uptake by macrophages. ${ }^{34,35}$ Additionally, MEC expressed surface calreticulin and CD91, thought to act together to promote the binding of macrophages to collectin-opsonized apoptotic cells. ${ }^{36,37}$
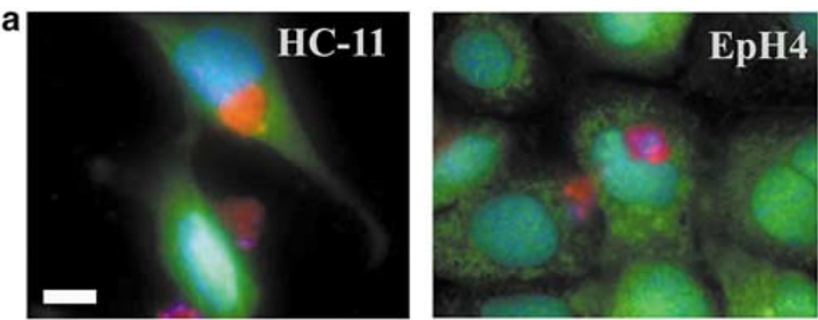

b

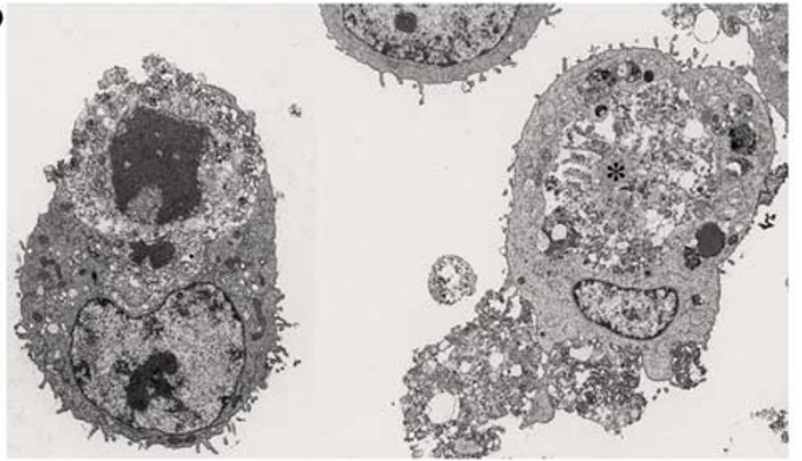

Figure 2 MEC bind and engulf apoptotic cells in vitro. (a) $\mathrm{HC}-11$ and $\mathrm{EpH} 4$ cells, labeled with Cell Tracker Green, were incubated with Texas red-labeled apoptotic HC-11 cells. The complexes were counterstained with Hoechst. Bar is $5 \mu \mathrm{m}$. Large vacuoles within the green phagocytes are evident with red-stained apoptotic bodies within. (b) $\mathrm{HC}-11$ cells were incubated with apoptotic $\mathrm{HC}-11$ cells and the complexes were processed for electron microscopy. Two phagocytic complexes, one with dead material inside a large phagosome (asterisk) are shown 


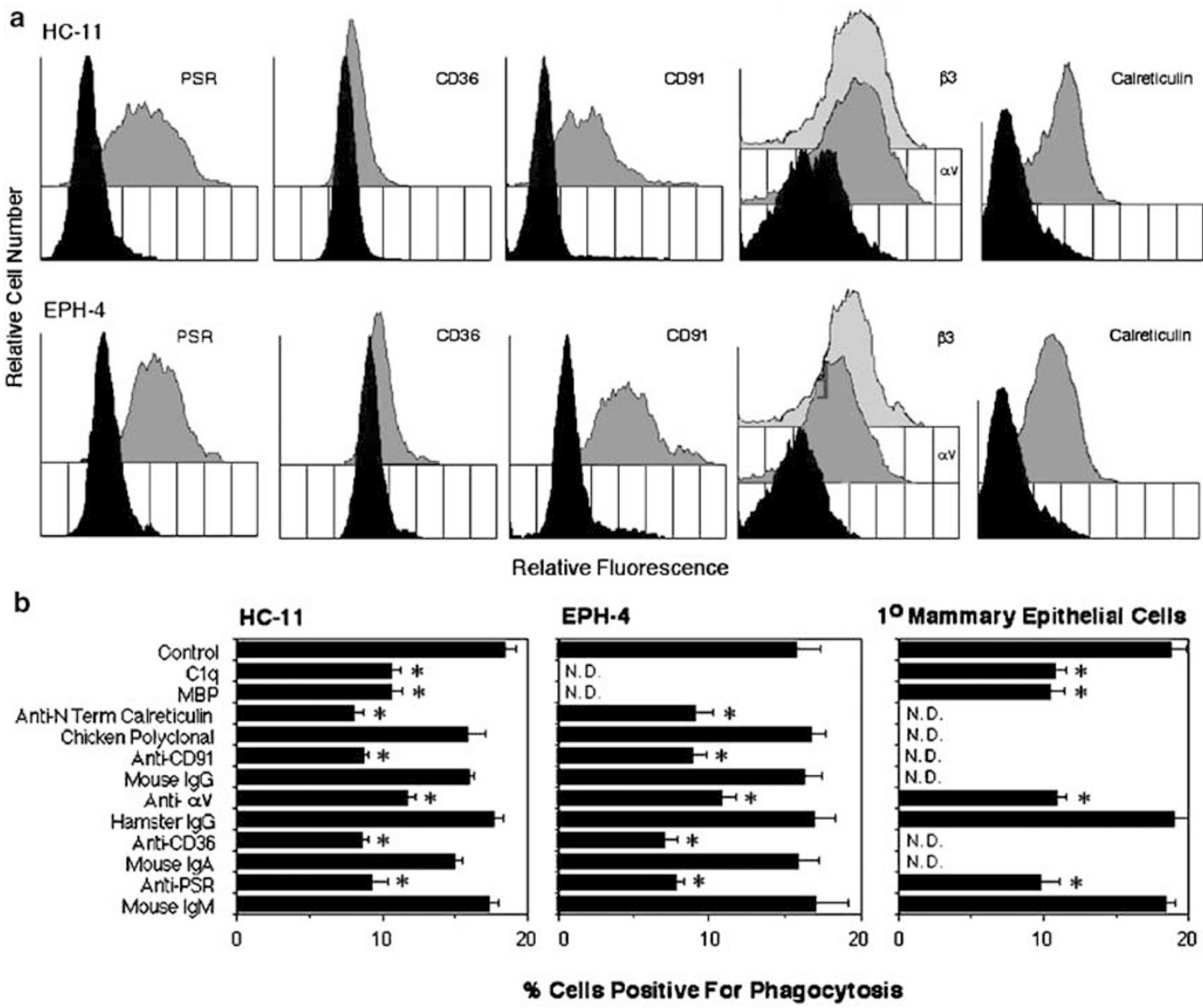

Figure 3 MEC express and utilize several receptors to bind and engulf apoptotic cells. (a) Analysis of receptor expression on $\mathrm{HC}-11$ and EpH4 cells by flow cytometry. The isotype control for each antibody is shown in black with specific staining shown in gray. (b) $\mathrm{HC}-11$, EpH-4, or primary mouse mammary epithelial cells (PMEC) were cultured in 24-well plates. Potential inhibitors of uptake were added $30 \mathrm{~min}$ prior to addition of apoptotic HC-11 cells as the target. The cells were incubated for $3 \mathrm{~h}$, then washed and fixed. Phagocytosis is expressed as \% epithelial cells positive for apoptotic bodies. $N=12 \pm$ S.E.M. for HC-11 and PMEC; $N=3 \pm$ for EpH 4 cells. ${ }^{*}$ Represents those numbers significantly different from the control phagocytosis $(P<0.0001)$. N.D. indicates those inhibitors that are not determined. C1q is the first component of complement; MBL is mannose-binding lectin, Anti-N term calreticulin is the antibody directed against the $\mathrm{N}$ terminus of calreticulin and the chicken polyclonal is the isotype control, anti-PSR is the monoclonal antibody $217 \mathrm{G} 8 \mathrm{E} 9$. For each antibody, the isotype control is shown directly beneath

Lastly MEC expressed PSR. ${ }^{38}$ These cells were tested for surface expression of scavenger receptor $A, C D 14$, and CD11b/CD18 (Mac-1) implicated in uptake of apoptotic cells by macrophages, ${ }^{39-43}$ but were found to be negative (not shown). These cells also do not express classical $F_{c}$ receptors and preliminary experiments suggested tht they do not engulf cells opsonized with mouse IgG (data not shown).

In Figure 3b, we show that antibodies to calreticulin, CD91, PSR, CD36, and the $\alpha_{v} \beta_{3} \mathrm{VnR}$ reduced phagocytosis of apoptotic $\mathrm{HC}-11$ cells by MEC. In addition, preincubation of the epithelial phagocytes with $\mathrm{C} 1 \mathrm{q}$ or mannose-binding lectin also blocked uptake of apoptotic cells by $\mathrm{HC}-11$ and PMEC, as was observed for macrophages. ${ }^{36}$

\section{Mammary epithelial cells express PSR on their cell surfaces in a punctate pattern}

We had demonstrated expression of PSR on the cell surface of epithelial cells initially by flow cytometry. We then undertook to demonstrate its presence by immunohistochemistry utilizing monoclonal antibody 217G8E9 (mAb217). The receptor appeared to be localized in small, undefined membrane microdomains on the surface. Background binding of nonspecific mouse IgM to these cells was minimal (Figure 4).

\section{Mammary epithelial cells respond to apoptotic cells by releasing TGF $\beta$ and downregulating endotoxin-induced TNF $\alpha$}

We and others ${ }^{44-47}$ have shown that macrophages exposed to apoptotic cells release anti-inflammatory mediators. These results can be mimicked by exposure to phosphatidylserinecontaining liposomes or by direct stimulation of the PSR by the mAb217. Figure 5 shows that mammary epithelial cells have the same response. $\mathrm{HC}-11$ cells stimulated with $2 \mu \mathrm{g} / \mathrm{ml}$ lipopolysaccharide (Escherichia coll) for $24 \mathrm{~h}$ secreted TNF $\alpha$ (Figure 5a) and MIP2 (Figure 5b). This response was abrogated by concurrent stimulation of the PtdSerR with 

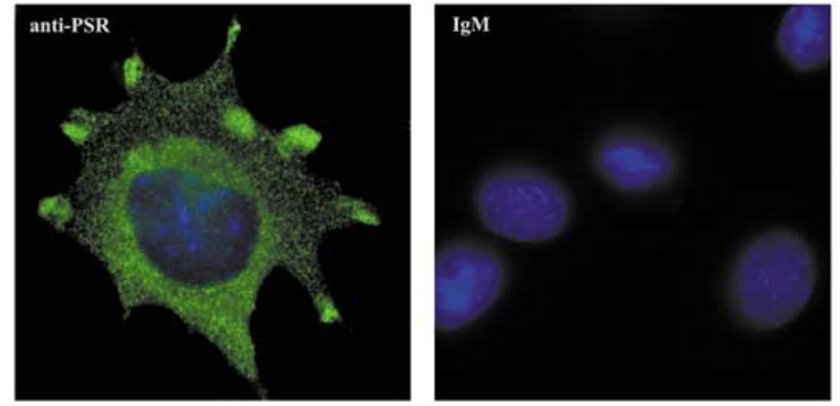

Figure 4 The PSR is expressed on the surface of cultured MEC. (a) Immunostaining of $\mathrm{HC}-11$ cells with $\mathrm{mAb} 217$ (shown in green) shows a punctate, surface localization of the PtdSerR. Cells are counterstained with DAPI. 'IgM' denotes the isotype control for anti-PtdSerR antibody

either mAb217 or phosphatidylserine-expressing apoptotic cells (Jurkat $T$ cells). The inhibition appeared to be specifically mediated by an interaction between phosphatidylserine on the dying cell and PSR, as apoptotic PLB 985 cells, which fail to expose phosphatidyserine ${ }^{48}$ had no effect. As was observed for macrophages, ${ }^{45}$ incubation of endotoxin-stimulated HC-11 cells with anti-TGF $\beta$ antibody partially blocked $(59 \pm 5.2 \%)$ the anti-inflammatory effects of the apoptotic cells, suggesting that TGF $\beta$ plays a role in the anti-inflammatory effects of apoptotic cells on epithelial proinflammatory cytokine production. In fact, HC-11 cells (Figure 5c) and PMEC (Figure 5d) isolated from a mid-pregnant mouse mammary gland were found to secrete TGF $\beta$ in response to apoptotic cells.

\section{Discussion}

We have shown that MEC, like macrophages, will bind and engulf apoptotic cells and that the consequences of such engulfment include the release of anti-inflammatory mediators and the repression of proinflammatory mediators. Further, we have shown that these cells utilize several receptors during the binding and phagocytic processes, and that mammary epithelial cells, like macrophages, respond to triggering of the PSR by membrane ruffling, suggesting that the mechanisms utilized for engulfment and many of the receptors are conserved among mammalian phagocytes, whether professional or not.

We have found that uptake of apoptotic cells by MEC in vitro is relatively inefficient when compared with that for macrophages. Our previous work has suggested that $40-60 \%$ of macrophages contain apoptotic cells after $30 \mathrm{~min}$, whereas the maximal percentage of epithelial cells was only $15-20 \%$ even after $4 \mathrm{~h}$ of incubation with apoptotic cells. The reasons for these differences and whether they apply in vivo are not known. Parnaik et al. ${ }^{49}$ compared the uptake of apoptotic cells by brain macrophages and microglia with uptake by lens epithelial cells and BHK cells. They found that while the nonprofessional phagocytes readily bound apoptotic cells, they did not ingest them for several hours, and concluded that apoptotic cells must develop additional surface changes that trigger engulfment. An alternate interpretation is that amateur phagocytes require induction of competency to phagocytose, which is acquired during the long binding period observed by Parnaik. Wood et al. ${ }^{13}$ found that while apoptotic cell

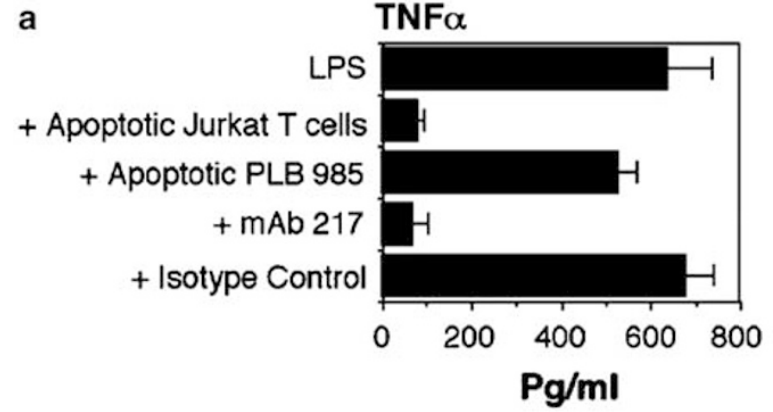

b

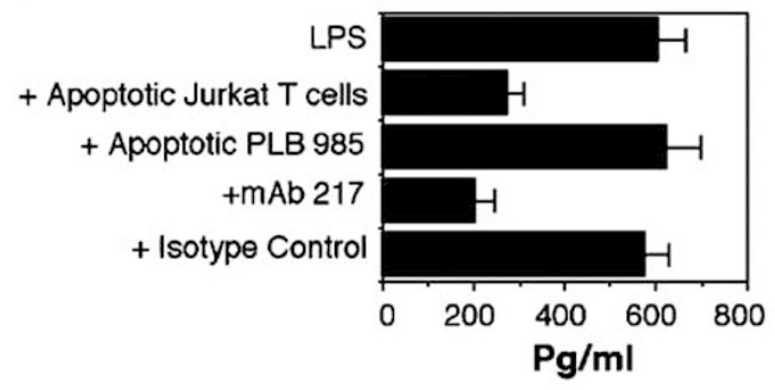

C

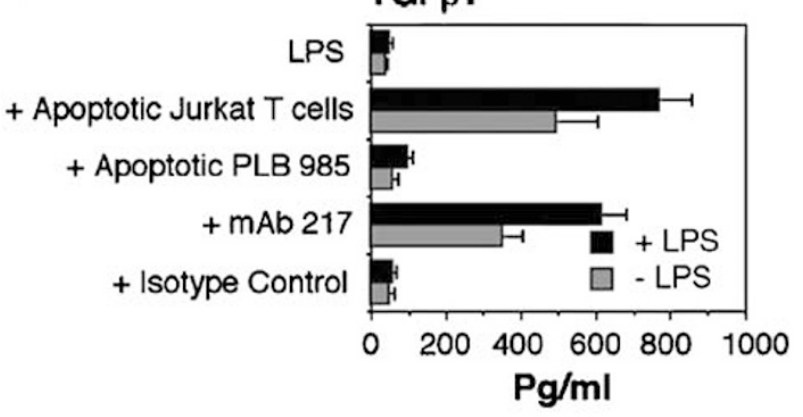

d

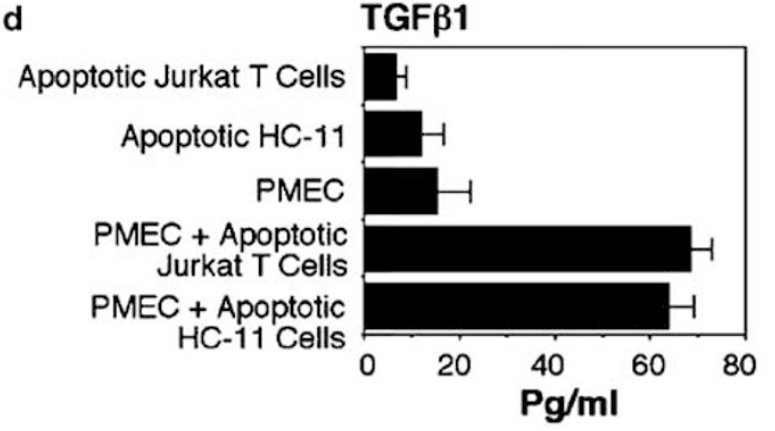

Figure 5 MEC release TGF $\beta$ and repress LPS-stimulated TNF $\alpha$ and MIP2 release following exposure to phosphatidylserine on apoptotic cells. (a) HC-11 cells were treated with LPS in the presence or absence of apoptotic Jurkat T cells (PtdSer positive by annexin V binding), apoptotic PLB 985 cells (PtdSer negative by annexin V), mAb 217, or its isotype control. After $24 \mathrm{~h}$, the medium was collected and analyzed for TNF $\alpha$ by ELISA. TNF $\alpha$ was not measurable in the medium from HC-11 cells not stimulated by LPS (not shown). (b) HC-11 cells were treated as described for (a) and supernatants were evaluated for MIP2. MIP2 was not measurable in supernatants from $\mathrm{HC}-11$ cells not stimulated by LPS (not shown). (c) HC-11 cells were treated as described for (a) and (b); supernatants were evaluated for TGF $\beta 1$ levels by ELISA. (d) Primary mammary epithelial cells (PMEC) were cultured as described in Materials and Methods. Apoptotic HC-11 cells and apoptotic Jurkat T cells were cultured alone or with the PMEC for $24 \mathrm{~h}$, then supernatants collected and evaluated for the production of $\operatorname{TGF} \beta$ by ELISA 
clearance in the developing limb bud was delayed in the absence of macrophages, the limb developed normally. These observations suggest that while macrophage removal of apoptotic bodies may be more efficient, amateur phagocytes can and will engulf apoptotic cells when macrophages are absent. Macrophages appear to have many more receptors that they can dedicate for apoptotic cell engulfment when compared to amateur phagocytes, and these cells certainly have evolved to be highly efficient at phagocytosis of many particles. Yet, engulfment of apoptotic cells in animals such as the nematode worm Caenorhabditis elegans is efficient and is mediated by nonmacrophages, suggesting that removal of dying self is conserved throughout the animal kingdom. In fact, the mechanical aspects of apoptotic cell phagocytosis appear to be preserved, as mammalian homologues for many of the $C$. elegans engulfment genes have been identified and characterized. ${ }^{50-56}$

The ability of MEC to engulf apoptotic bodies and their ability to secrete anti-inflammatory mediators in response suggest an important role for amateur phagocytes in the gland. During mammary involution, significant cell death occurs prior to dissolution of the basement membrane supporting the alveolar epithelial cells. During the first 4 days of murine involution, we have found that the sole phagocyte is the epithelial cell (Monks $\mathrm{J}$ et al., submitted for publication). After that time, macrophages have migrated into the tissue and are believed to participate both in the removal of residual apoptotic bodies and remodeling of the tissue. ${ }^{14}$ Thus, it is entirely possible that mediators secreted by MEC following exposure to apoptotic cells helps to call in macrophages, facilitate remodeling, and inhibits the migration or activation of inflammatory neutrophils into the tissue. Activation of a fullblown immune response, as seen in dairy cows with mastitis, leads to tissue damage, the inability of the gland to fully regenerate, and decreased milk production. Thus, the response of the epithelium to apoptosis of its neighbors is crucial to both the immune barrier and the subsequent lactational function of the gland. In a broader sense, these data support the hypothesis that during normal cell turnover in epithelial tissues, epithelial phagocytes are major contributors to dead cell removal, and that they therefore contribute significantly to tissue homeostasis.

\section{Materials and Methods}

\section{Cell culture}

$\mathrm{HC}-11$ cells were cultured according to published protocols, ${ }^{57}$ in RPMI 1640 medium with $10 \%$ fetal calf serum, penicillin, streptomycin supplemented with $5 \mu \mathrm{g} / \mathrm{ml}$ insulin and $10 \mathrm{ng} / \mathrm{ml}$ epidermal growth factor, and passed twice per week, before confluency. EpH4 cells were grown in Dulbecco's modified Eagle's medium (high glucose) with $5 \%$ fetal calf serum, penicillin, and streptomycin. PMEC were isolated from day 15 pregnant CD1 mice as described previously, ${ }^{58}$ thawed and cultured on rat tail collagen for $5-7$ days prior to use in experiments.

\section{Induction of apoptosis}

$\mathrm{HC}-11$ cells were induced to undergo apoptosis by culturing them in the absence of growth factors (in RPMI containing $100 \mathrm{U} / \mathrm{ml}$ penicillin, $100 \mu \mathrm{g} /$ $\mathrm{ml}$ streptomycin, and $2 \mathrm{mM}$ glutamine $+2 \%$ BSA as protein source) in Teflon plates to prevent adherence. This was previously shown to induce apoptosis in this cell line. ${ }^{59}$ Apoptosis was assessed by morphology using light microscopy and by ability to bind to FITC-conjugated annexin V (Pharmingen). In all, $70 \pm 18 \%$ cells were apoptotic by morphological assessment, with $77 \pm 20 \%$ annexin positive, at $4 \mathrm{~h} ; 8 \%$ were trypan blue positive; therefore, these were used for subsequent phagocytosis and cytokine assays. Apoptosis was induced in Jurkat $\mathrm{T}$ cells (a human $\mathrm{T}$ lymphocyte cell line) and PLB 985 cells (a human monomyelocytic cell line) using UV irradiation as described previously. ${ }^{48}$ Apoptosis was assessed by morphology using light microscopy; loss of phospholipid asymmetry and exposure of phosphatidylserine on the outer leaflet of the plasma membrane was assessed by the ability to bind Alexa-488conjugated annexin V (Molecular Probes). As we have shown previously, Jurkat $T$ cells express phosphatidylserine externally following induction of apoptosis, and PLB 985 cells do not. ${ }^{48}$

\section{Histochemistry}

Visualization of uptake: $\mathrm{HC}$-11 cells were induced to undergo apoptosis as described above. After $10 \mathrm{~h}$, the nonadherent cells were labeled with Texas red-X-SE (Molecular Probes, Eugene, OR, USA) and fed to CellTracker green (Molecular Probes, Eugene, OR, USA) labeled HC-11 cells on glass coverslips. After a 4-hour incubation, unbound cells were washed away and the coverslips were moved into ice-cold fixative: $3 \%$ paraformaldehyde, $3 \%$ sucrose in Dulbecco's PBS $\left(+\mathrm{Ca}^{2+} / \mathrm{Mg}^{2+}\right)$. The cells were counterstained with Hoechst 33452 at $0.5 \mu \mathrm{g} / \mathrm{ml}$ for $30 \mathrm{~min}$, rinsed with PBS and mounted onto slides with a glycerol-based mounting medium with o-phenylenediamine (opda) antifade.

\section{Immunohistochemistry for expression of PtdSerR}

Staining for surface receptors was performed without permeabilization of the cells. Briefly, HC-11 or EpH4 cells were rinsed with HBSS and incubated with $\mathrm{mAB} 217 \mathrm{G} 8 \mathrm{E} 9$ or mouse IgM isotype control in HBSS for 30 min at $4^{\circ} \mathrm{C}$. Cells were rinsed with ice-cold PBS and fixed for $20 \mathrm{~min}$ on ice. The cells were permeabilized with TX100 as above and blocked with $1 \%$ ovalbumin in PBS. Fluorescent secondary antibody was added with DAPI or Hoechst 33258 to visualize nuclei. The cells were incubated with the fluors for $45 \mathrm{~min}$, soaked in PBS overnight and mounted with opda/glycerol mounting medium.

\section{Staining of mammary tissue}

Mice were anaesthetized with Nembutal (sodium pentobarbital at $0.1 \mathrm{mg} / \mathrm{g}$ body weight) and intracardially perfused with ice-cold Dulbecco's PBS, followed by $2 \%$, then $4 \%$ formaldehyde solution in PBS. Tissues were dissected, further immersion fixed for $4 \mathrm{~h}$ and frozen in methylbutane cooled with liquid nitrogen. Frozen sections, 8- $\mu \mathrm{m}$ thick, were collected onto Cell-Tak-coated coverslips and staining proceeded as described for the cultured cells above. Cytodeath, an antibody to caspase-cleaved keratin-18, was used according to the manufacturer's instructions (Roche Molecular Biochemicals).

Imaging: Imaging was carried out on an epifluorescent, multifluor imaging, deconvolution and analysis system with SlideBook software (Intelligent Imaging Innovations, Inc., Denver, CO, USA).

\section{Electron microscopy}

Apoptotic HC-11 cells were incubated with HC-11 cell phagocytes for $4 \mathrm{~h}$ at $37^{\circ} \mathrm{C}$. Unbound cells were washed away with ice-cold HBSS and cell 
dissociation solution, consisting of HBSS $\left(-\mathrm{Ca}^{2+} / \mathrm{Mg}^{2+}\right)+10 \mathrm{mM}$ EDTA, was added. After $15 \mathrm{~min}$, on ice, the cells were lifted with a cell lifter and tritrated to further dissociate. The cells were then pelleted from the dissociation solution and resuspended in $1.5 \%$ glutaraldehyde in cacodylate buffer. The cells were fixed overnight at $4^{\circ} \mathrm{C}$ and then processed for electron microscopy as previously described. ${ }^{60}$

Similarly, formaldehyde-perfused tissue was further fixed, overnight in $1 \%$ glutaraldehyde, $0.5 \%$ acrolein in cacodylate buffer and processed for electron microscopy.

\section{Flow cytometry}

$\mathrm{HC}-11, \mathrm{EpH}-4$ cells, and PMEC were plated in $100 \mathrm{~mm}$ dishes and cultured in growth medium. Cells were harvested when the confluency reached $40-50 \%$ by incubating in Hank's BSS $\left(-\mathrm{Ca}^{2+} / \mathrm{Mg}^{2+}\right)$ containing $5 \mathrm{mM}$ EDTA and gentle scraping. Following washing in HBSS, 0.5 million cells per condition were resuspended in $100 \mu \mathrm{lHBSS}$ containing $2 \%$ FCS, plus primary antibodies. Those used included $\mathrm{mAb} 217 \mathrm{G} 8 \mathrm{E} 9$ or its isotype control (mouse lgM, $200 \mu \mathrm{g} / \mathrm{ml}$ ), ${ }^{38}$ anti-mouse CD 51 (anti- $\alpha_{\mathrm{v}}$, hamster IgG, Pharmingen, $20 \mu \mathrm{g} / \mathrm{ml})$, anti-mouse $\operatorname{CD61}\left(\beta_{3}\right.$, hamster IgG Pharmingen, $20 \mu \mathrm{g} / \mathrm{ml}$ ) anti-calreticulin N-terminal (ABR, chicken polyclonal, 1:10), anti-CD91 $\alpha$ (mouse IgG1, American Diagnostica, $10 \mu \mathrm{g} /$ $\mathrm{ml}$ ), anti-mouse CD36 (mouse IgA, Cascade Biosciences, $10 \mu \mathrm{g} / \mathrm{ml}$ ). All isotype controls were used at same concentration as the specific primary antibodies. Secondary antibodies were Cy3-conjugated $\mathrm{F}(\mathrm{ab})_{2}{ }_{2}$ antibodies from Jackson ImmunoResearch or whole immunoglobulin from Pharmingen (FITC-conjugated anti-mouse $\lg \mathrm{A}$ ).

\section{Phagocytosis assays}

Apoptosis was induced in $\mathrm{HC}-11$ cells as described above. Then, 3-5 million cells from the apoptotic population were added in a total volume of $1 \mathrm{ml}$ of mammary epithelial cell growth medium (see above, contains $10 \%$ FCS) to 24-well plates containing viable $\mathrm{HC}-11$ cells, viable $\mathrm{EpH} 4$ cells, or PMEC, which had been preincubated for 30 min with anti-PtdSerR (mAb 217 ) or its isotype control (mouse $\mathrm{lgM}$ ) at $200 \mu \mathrm{g} / \mathrm{ml}$, anti-CD $91 \alpha$ (American Diagnostica) or its isotype control (mouse lgG1, Pharmingen) at $50 \mu \mathrm{g} / \mathrm{ml}$, anti-mouse CD36 (Cascade Biosciences) or its isotype control (mouse IgA, Pharmingen) at $100 \mu \mathrm{g} / \mathrm{ml}$, anti- $\alpha_{v}$ (anti-mouse CD51, Pharmingen, at $100 \mu \mathrm{g} / \mathrm{ml}, \mathrm{C} 1 \mathrm{q}$ at $25 \mu \mathrm{g} / \mathrm{ml}$, mannose-binding protein (MBP) at $25 \mu \mathrm{g} / \mathrm{ml}$. Viable and apoptotic cells were incubated for $3 \mathrm{~h}$. The cells were then washed three to four times with ice-cold PBS, fixed with $1 \%$ bufferend normal formalin and stained with Diff-Quik (Baxter Healthcare Corp.). Phagocytosis was scored by light microscopy. A minimum of 200 cells was counted in each duplicate well. The number of epithelial cells containing phagocytosed material was counted, and the percentage of positive cells was determined. Results from duplicate samples were averaged to generate the mean for each condition.

\section{Cytokine assays}

$\mathrm{HC}-11$ cells were plated at 0.25 million cells per well in 24-well plates in growth medium (RPMl $+10 \%$ FCS + EGF $(10 \mathrm{ng} / \mathrm{ml})+$ insulin $(5 \mu \mathrm{g} /$ $\mathrm{ml})+$ glutamine $(2 \mathrm{mM})+$ penicillin $(100 \mu \mathrm{g} / \mathrm{ml})+$ streptomycin $(100 \mu \mathrm{g} /$ $\mathrm{ml})$ ). After overnight incubation, the medium was replaced with serum-free medium ( $X$-Vivo, Biowhittaker) containing EGF $(10 \mathrm{ng} / \mathrm{ml})$ and insulin $(5 \mu \mathrm{g} / \mathrm{ml})$. Apoptotic Jurkat T cells (3 million per well), apoptotic PLB 985 cells (3 million per well), mAb 217G8E9 $(200 \mu \mathrm{g} / \mathrm{ml})$, or its isotype control, mouse $\operatorname{lgM}(200 \mu \mathrm{g} / \mathrm{ml})$ were added in the presence or absence of LPS (E.coli 011:B4, $1 \mu \mathrm{g} / \mathrm{ml}$ ). The cells were then cultured for an additional
$24 \mathrm{~h}$. Supernatants were collected, centrifuged to remove particulate matter, and frozen at $-70^{\circ} \mathrm{C}$ until analyzed by ELISA for TNF $\alpha$, MIP2, IL-10 (R \& D Systems), and TGF $\beta 1 .^{61}$ PMEC were obtained from day 15 pregnant CD1 outbred mice as described above. For these experiments, the normal growth medium was removed and replaced with $X$-vivo containing EGF and insulin (same concentrations used for $\mathrm{HC}-11$ as described above). Then, either apoptotic Jurkat T cells or apoptotic $\mathrm{HC}$ - 11 cells were added ( 5 million of each per well) and the PMEC were cultured for an additional $24 \mathrm{~h}$. Supernatants were collected, centrifuged to remove particulate debris, and frozen at $-70^{\circ} \mathrm{C}$ until analyzed for TGF $\beta 1$ by ELISA. ${ }^{61}$

\section{Acknowledgements}

We thank Jay Westcott for invaluable assistance with the cytokine ELISA assays, Pat Foley at Cascade Biosciences for the gift of anti-mouse CD36 antibody, and Gail Smith for electron microscopy assistance. This work was supported by NIH grant numbers P01 HD 38129, R01 GM60449, and P30 CA 46934 as well as the Florence Myers Goldhamer Fellowship in Pediatric Allergy and Immunology.

\section{References}

1. Geske FJ, Monks J, Lehman L and Fadok VA (2002) The role of the macrophage in apoptosis: hunter, gatherer, and regulator. Int. J. Hematol. 76: $16-26$

2. Savill $J$ and Fadok $V(2000)$ Corpse clearance defines the meaning of cell death. Nature 407: 784-788

3. Gregory CD (2000) CD14-dependent clearance of apoptotic cells: relevance to the immune system. Curr. Opin. Immunol. 12: 27-34

4. Gregory CD (2000) Non-inflammatory/anti-inflammatory CD14 responses: CD14 in apoptosis. Chem. Immunol. 74: 122-140

5. Fadok VA, Bratton DL and Henson PM (2001) Phagocyte receptors for apoptotic cells: recognition, uptake, and consequences. J. Clin. Invest. 108: 957-962

6. Henson PM, Bratton DL and Fadok VA (2001) The phosphatidylserine receptor: a crucial molecular switch? Nat. Rev. Mol. Cell. Biol. 2: 627-633

7. Savill J, Dransfield I, Gregory C and Haslett C (2002) A blast from the past: clearance of apoptotic cells regulates immune responses. Nat. Rev. Immunol. 2: 965-975

8. Kreiser RJ and White K (2002) Engulfment mechanisms of apoptotic cells. Curr. Opin. Cell Biol. 14: 734-738

9. Balasubramanian K and Schroit AJ (2003) Aminophospholipid asymmetry: a matter of life and death. Annu. Rev. Physiol. 65: 701-734

10. de Freitas Balanco JM, Moreira ME, Bonoma A, Bozza PT, Amarante-Mendes G, Pirmez C and Barcinski MA (2001) Apoptotic mimicry by an obligate intracellular parasite downregulates macrophage microbicidal activity. Curr. Biol. 11: 1870-1873

11. Freire-de-Lima CG, Nascimento DO, Soares MB, Bozza PT, Castro-Faria-Neto HC, de Mello FG, DosReis GA and Lopes MF (2000) Uptake of apoptotic cells drives the growth of a pathogenic trypanosome in macrophages. Nature 403: 199-203

12. Tripathi A and Gupta CM (2003) Transbilayer translocation of membrane phosphatidylserine and its role in macrophage invasion in Leishmania promastigotes. Mol. Biochem. Parasitol. 128: 1-9

13. Wood W, Turmaine M, Weber R, Camp V, Maki RA, McKercher SR and Martin P (2000) Mesenchymal cells engulf and clear apoptotic footplate cells in macrophageless PU.1 null mouse embryos. Development 127: 5245-5252

14. Walker NI, Bennet RE and Kerr JFR (1989) Cell death by apoptosis during involution of the lactating breast in mice and rats. Am. J. Anat. 185: 19-32

15. Sexton DW, Blaylock MG and Walsh GM (2001) Human alveolar epithelial cells engulf apoptotic eosinophils by means of integrin- and phosphatidylserine receptor-dependent mechanisms: a process upregulated by dexamethasone. J. Allergy Clin. Immunol. 108: 962-969 
16. Walsh GM, Sexton DW, Blaylock MG and Convery CM (1999) Resting and cytokine-stimulated human small airway epithelial cells recognize and engulf apoptotic eosinophils. Blood 94: 2827-2835

17. Hughes J, Liu Y, Van Damme J and Savill J (1997) Human glomerular mesangial cell phagocytosis of apoptotic neutrophils: mediation by a novel CD36-independent vitronectin receptor/thrombospondin recognition mechanism that is uncoupled from chemokine secretion. J. Immunol. 158: 4389-4397

18. Liu Y, Cousin JM, Hughes J, Van Damme J, Seckl JR, Haslett C, Dransfield I, Savill J and Rossi AG (1999) Glucocorticoids promote nonphlogistic phagocytosis of apoptotic leukocytes. J. Immunol. 162: 3639-3646

19. Savill J, Smith J, Sarraf C, Ren Y, Abbott F and Rees A (1992) Glomerular mesangial cells and inflammatory macrophages ingest neutrophils undergoing apoptosis. Kidney Int. 42: 924-936

20. Bennett MR, Gibson DF, Schwartz SM and Tait JF (1995) Binding and phagocytosis of apoptotic vascular smooth muscle cells is mediated in part by exposure of phosphatidylserine. Circ. Res. 77: 1136-1142

21. Dini L (1998) Endothelial liver cell recognition of apoptotic peripheral blood lymphocytes. Biochem. Soc. Trans. 26: 635-639

22. Dini L (2000) Recognizing death: liver phagocytosis of apoptotic cells. Eur. J. Histochem. 44: 217-227

23. Dini L, Autuori F, Lentini A, Oliverio S and Piacentini M (1992) The clearance of apoptotic cells in the liver is mediated by the asialoglycoprotein receptor. FEBS Lett. 296: 174-178

24. Dini L and Carla EC (1998) Hepatic sinusoidal endothelium heterogeneity with respect to the recognition of apoptotic cells. Exp. Cell Res. 240: 388-393

25. Dini L, Lentini A, Diez GD, Rocha M, Falasca L, Serafino $L$ and VidalVanaclocha $F$ (1995) Phagocytosis of apoptotic bodies by liver endothelial cells. J. Cell Sci. 108: 967-973

26. Falasca L, Bergamini A, Serafino A, Balabaud C and Dini L (1996) Human Kupffer cell recognition and phagocytosis of apoptotic peripheral blood lymphocytes. Exp. Cell Res. 224: 152-162

27. Oka K, Sawamura T, Kikuta K, Itokawa S, Kume N, Kita T and Masaki T (1998) Lectin-like oxidized low-density lipoprotein receptor 1 mediates phagocytosis of aged/apoptotic cells in endothelial cells. Proc. Natl. Acad. Sci. USA 95: 9535-9540

28. Hess KL, Tudor KS, Johnson JD, Osati-Ashtiani F, Askew DS and Cook-Mills JM (1997) Human and murine high endothelial venule cells phagocytose apoptotic leukocytes. Exp. Cell Res. 236: 404-411

29. Boudjellab N, Chan-Tang HS, Li X and Zhao X (1998) Interleukin 8 reponse by bovine mammary epithelial cells to lipopolysaccharide stimulation. Am. J. Vet. Res. 59: 1563-1567

30. Boudjellab N, Chan-Tang HS and Zhao X (2000) Bovine interleukin-1 expression by cultured mammary epithelial cells (MAC-T) and its involvement in the release of MAC-T derived interleukin-8. Comp. Biochem. Physiol. A Mol. Integr. Physiol. 127: 191-199

31. Doppler W, Groner B and Ball RK (1989) Prolactin and glucocorticoid hormones synergistically induce expression of transfected rat beta-casein gene promoter constructs in a mammary epithelial cell line. Proc. Natl. Acad. Sci. USA 86: $104-108$

32. Reichmann E, Ball R, Groner B and Friis RR (1989) New mammary epithelia and fibroblastic cell clones in coculture form structures competent to differentiate functionally. J. Cell Biol. 108: 1127-1138

33. Hoffmann PR, deCathelineau AM, Ogden CA, Leverrier Y, Bratton DL, Daleke DL, Ridley AJ, Fadok VA and Henson PM (2001) Phosphatidylserine (PS) induces PS receptor-mediated macropinocytosis and promotes clearance of apoptotic cells. J. Cell Biol. 155: 649-660

34. Savill J, Dransfield I, Hogg N and Haslett C (1990) Vitronectin receptormediated phagocytosis of cells undergoing apoptosis. Nature 343: 170-173

35. Savill J, Hogg N, Ren Y and Haslett C (1992) Thrombospondin cooperates with CD36 and the vitronectin receptor in macrophage recognition of neutrophils undergoing apoptosis. J. Clin. Invest. 90: 1513-1522

36. Ogden CA, de Cathelineau A, Hoffmann PR, Fadok VA, Bratton DL and Henson PM (2001) C1q and mannose binding lectin engagement of cell surface calreticulin and CD91 initiates macropinocytosis and uptake of apoptotic cells. J. Exp. Med. 194: 781-795

37. Vandivier RW, Ogden CA, Fadok VA, Hoffmann PR, Brown KK, Botto M, Walport MJ, Fisher JH, Henson PM and Greene KE (2002) Role of surfactant proteins $\mathrm{A}, \mathrm{D}$, and $\mathrm{C} 1 \mathrm{q}$ in the clearance of apoptotic cells in vivo and in vitro: calreticulin and CD91 as a common collectin receptor complex. J. Immunol. 169: 3978-3986

38. Fadok VA, Bratton DL, Rose DM, Pearson A, Ezekewitz RA and Henson PM (2000) A receptor for phosphatidylserine-specific clearance of apoptotic cells. Nature 405: 85-90

39. Platt N, Suzuki H, Kurihara Y, Kodama T and Gordon S (1996) Role for the class $\mathrm{A}$ macrophage scavenger receptor in the phagocytosis of apoptotic thymocytes in vitro. Proc. Natl. Acad. Sci. USA 93: 12456-12460

40. Terpstra V, Kondratenko N and Steinberg D (1997) Macrophages lacking scavenger receptor $\mathrm{A}$ show a decrease in binding and uptake of acetylated low-density lipoprotein and of apoptotic thymocytes, but not of oxidatively damaged red blood cells. Proc. Natl. Acad. Sci. USA 94: $8127-8131$

41. Devitt A, Moffatt OD, Raykundalia C, Capra JD, Simmons DL and Gregory CD (1998) Human CD14 mediates recognition and phagocytosis of apoptotic cells. Nature 392: 505-509

42. Takizawa F, Shoutaro T and Nagasawa S (1996) Enhancement of macrophage phagocytosis upon iC3b deposition on apoptotic cells. FEBS Lett. 397: 269-272

43. Mevorach D, Mascarenhas JO, Gershov D and Elkon KB (1998) Complementdependent clearance of apoptotic cells by human macrophages. J. Exp. Med. 188: 2313-2320

44. Fadok VA, Bratton DL, Guthrie L and Henson PM (2001) Differential effects of apoptotic vs lysed cells on macrophage production of cytokines: role of proteases. J. Immunol. 161: 5873-5879

45. Fadok VA, Bratton DL, Konowal A, Freed PW, Westcott JY and Henson PM (1998) Macrophages that have ingested apoptotic cells in vitro inhibit proinflammatory cytokine production through autocrine/paracrine mechanisms involving TGF-beta, PGE2, and PAF. J. Clin. Invest. 101: 890898

46. Huynh M-L, Fadok VA and Henson PM (2002) TGFb1 secretion and resolution of inflammation are increased after phosphatidylserine-dependent ingestion of apoptotic cells. J. Clin. Invest. 109: 41-50

47. Voll RE, Herrmann M, Roth EA, Stach C, Kalden JR and Girkontaite I (1997) Immunosuppressive effects of apoptotic cells (letter). Nature 390: 350-35

48. Fadok VA, de Cathelineau A, Daleke DL, Henson PM and Bratton DL (2001) Loss of phospholipid asymmetry and surface exposure of phosphatidylserine is required for phagocytosis of apoptotic cells by macrophages and fibroblasts. J. Biol. Chem. 276: 1071-1077

49. Parnaik RR, Raff MC and Scholes J (2000) Differences between the clearance of apoptotic cells by professional and non-professional phagocytes. Curr. Biol. 10: $857-860$

50. Ellis RE, Jacobson DM and Horvitz HR (1991) Genes required for the engulfment of cell corpses during programmed cell death in Caenorhabditis elegans. Genetics 129: 79-94

51. Su HP, Brugnera E, Van Criekinge W, Smits E, Hengartner M, Bogaert T and Ravichandran KS (2000) Identification and characterization of a dimerization domain in CED-6, an adapter protein involved in engulfment of apoptotic cells. J. Biol. Chem. 275: 9542-9549

52. Su HP, Nakada-Tsukui K, Tosello-Trampont AC, Li Y, Bu G, Henson PM and Ravichandran KS (2002) Interaction of CED-6/GULP, an adapter protein involved in engulfment of apoptotic cells with CED-1 and CD91/low density lipoprotein receptor-related protein (LRP). J. Biol. Chem. 277: 11772-11779

53. Tosello-Trampont AC, Brugnera E and Ravichandran KS (2001) Evidence for a conserved role for CRKII and Rac in engulfment of apoptotic cells. J. Biol. Chem. 276: 13797-13802

54. Brugnera E, Haney L, Grimsley C, Lu M, Walk SF, Tosello-Trampont AC, Macara IG, Madhani H, Fink GR and Ravichandran KS (2002) Unconventional Rac-GEF activity is mediated through the Dock180-ELMO complex. Nat. Cell Biol. 4: 574-582

55. Gumienny TL, Brugnera E, Tosello-Trampont AC, Kinchen JM, Haney LB, Nishiwaki K, Walk SF, Nemergut ME, Macara IG, Francis R, Schedl T, Qin Y, Van Aelst L, Hengartner MO and Ravichandran KS (2001) CED-12/ELMO, a novel member of the Crkll/Dock180/Rac pathway, is required for phagocytosis and cell migration. Cell 107: 27-41

56. Wang X, Wu YC, Fadok VA, Lee MC, Gengyo-Ando K, Cheng LC, Ledwich D, Hsu PK, Chen JY, Chou BK, Henson P, Mitani S and Xue D (2003) Cell corpse 
engulfment mediated by $C$. elegans phosphatidylserine receptor through CED5 and CED-12. Science 302: 1563-1566

57. Ball RK, Friis RR, Schoenenberger CA, Doppler W and Groner B (1988) Prolactin regulation of beta-casein gene expression and of a cytosolic 120-kd protein in a cloned mouse mammary epithelial cell line. EMBO J. 7: 2089-2095

58. Emerman JT and Pitelka DR (1977) Maintenance and induction of morphological differentiation in dissociated mammary epithelium on floating collagen membranes. In vitro 13: 316-328

59. Merlo GR, Graus-Porta D, Cella N, Marte BM, Taverna D and Hynes NE (1996) Growth, differentiation and survival of $\mathrm{HC} 11$ mammary epithelial cells: diverse effects of receptor tyrosine kinase-activating peptide growth factors. Eur. J. Cell Biol. 70: 97-105

60. Fadok VA, Savill JS, Haslett C, Bratton DL, Doherty DE, Campbell PA and Henson PM (1992) Different populations of macrophages use either the vitronectin receptor or the phosphatidylserine receptor to recognize and remove apoptotic cells. J. Immunol. 149: 4029-4035

61. Kench JA, Russell DM, Fadok VA, Young SK, Worthen GS, Jones-Carson J, Henson JE, Henson PM and Nemazee D (1999) Aberrant wound healing and TGF-beta production in the autoimmune-prone MRL/+ mouse. Clin. Immunol. 92: $300-310$ 